\title{
School readiness and pedagogies of Competence and Performance. Theorising the troubled relationship between early years and early years policy
}

School readiness is currently a strong focus for education policy in England (OFSTED 2014b). However, understanding what it means to be ready for school, and how this is reflected in policy and enacted in practice, are sites of contention. This paper explores the genesis of the current disparity in understandings in the context of the English education system. A comparison of discourses reveals how early years is informed by distinctly different discourses which, transformed into practice, require different pedagogical approaches. This disparity is theorised within Bernstein's Pedagogic Device and Pedagogies of Competence and Performance (Bernstein 2000). This provides a theoretical framework which enables articulation of how these discourses are transformed into practice and the resulting pedagogical practices which are shown to be distinctly different. The paper outlines how a politically driven change in discourse has resulted in enforced pedagogical change in early years and considers whether this is likely to achieve the stated aim of enabling all children to be ready for school. The implications for policy and practice are discussed.

Keywords: Bernstein, early years policy, children and childhood, Competence and Performance pedagogy, school readiness.

\section{Introduction}

School readiness is currently high on the political agenda in England. It is understood as the desire for children to arrive at school 'ready to learn' (Whitebread and Bingham $2011,1)$. This aspiration is, perhaps, not in itself contentious as there is a significant body of evidence that demonstrates the benefits of high-quality pre-school provision (DFE/IOE 2014; Dockett and Perry 2013; Burger 2010; Schweinhart et al. 2005). However, this issue is embedded in the wider context of conflicting pedagogies arising from differing conceptualisations of the nature and purpose of pre-school provision (Georgeson and Payler 2013). Dockett and Perry's (2013) review of international evidence on children's transition to school identifies a global pattern of trends and tensions. They observe that the notion of school readiness has assumed importance in the international literature, and note a general commitment to promoting children's readiness for school underpinned by the assumption that early experiences have been 
shown to have a positive impact on later outcomes. They conclude that, overall, international evidence is strongly focused on the preparedness of individual children, and caution that this focus on the readiness-attributes of individuals over broader conceptualisations of readiness has the potential to narrow the scope and focus of the debate. This focus, they argue, often simplifies the complexity of transition to school to a series of practices or actions. Other international evidence supports this view: Vandenbroeck, De Stercke, and Gobeyn (2013) observe this trend in Flanders, noting that school readiness is embedded within a preventative paradigm, and school failure perceived as a problem of individual children. This, they argue, has led to the pedagogisation of parenting in pursuit of school focused outcomes. Similarly, Haug (2013) outlines how in Norway, barnehage, a pre-school movement traditionally focused on play and social activities, has been drawn into a new national curriculum. This, Haug argues, marks a move towards the 'systematic learning of formalised subject content' (126) to ready individual children for school.

\section{School readiness: The English context}

In April 2014 Sir Michael Wilshire, Her Majesty’s Chief Inspector and head of Ofsted (Office for Standards in Education), launched Ofsted's first annual report dedicated to the early years - known in England as the foundation years, and covering the period between birth and the $31^{\text {st }}$ August following a child's fifth birthday (Ofsted 2014a). The report (Ofsted 2014b), supported by previous Ofsted evidence (Ofsted 2013), concludes that, despite significant investment and effort in the early years, the achievement gap in England between the poorest and those from more advantaged backgrounds still exists. It notes that this has persisted at the same level over the six years that benchmarks have been in place.

The report sets out the government's view of the purposes of early years provision in England and builds an argument about why this is not being achieved and what needs to happen to address the identified issues. Early years provision Ofsted $(2014 \mathrm{~b}, 9)$ argues has three main aims;

- helping to improve children's outcomes, and so putting them on the path to success in later life;

- enabling parents to work, 
- getting children into early years provision at an early age to provide an opportunity to identify and intervene earlier in potential problems.

More specifically the report calls for higher levels of funding and focus on children from poorer backgrounds, and a nationally comparable, standardised, baseline assessment to be completed at the start of Reception (the school year in which a child becomes five years old). This, it argues, should be a 'direct read' through from the current two-year-old check, so that 'it is obvious at the age of two if a child is, or is not, on track to be ready for school' (31). This is supported at policy level by the aspiration to replace the current Foundation Stage Profile with a baseline assessment (DFE 2014). This policy has, however, proved to be more complex to implement than initially anticipated (Standards and Testing Agency 2016).

Accompanying Ofsted's annual early years report is one that specifically explores the notion of school readiness: Are you ready? Good practice in school readiness. Whilst it is acknowledged that 'school readiness' is a slippery term, the report is clear: that the role of early years is preparation for school. Early years provision should focus on, and thus be defined by, the next stage of education, that of formal schooling. This is justified by the explicit argument that 'the quality of a child's early experience is vital for their future success' and 'crucial in countering the effects of socio-economic disadvantage' (Ofsted 2014c, 4). This marks the latest move in a raft of initiatives and interventions in early years by all governments in England since 1997 (Stagg 2012).

The supporting rhetoric is powerful. It would be difficult to justify a challenge to the assertion that early years provision has a significant role to play in children's learning and development. However, whilst there may be consensus about the importance of a policy focus on early years, the direction of policy is significantly more controversial (Moss 2013; Miller and Hevey 2012; Moyles 2012; House 2011; Pound and Miller 2011; OECD 2006).

Moss $(2007,2013)$ is particularly vocal in his opposition to the policy focus. He describes the rationale for action as instrumental. Current policy, he argues, views education settings as 'places first and foremost, for technical practice: places where 
society can apply powerful human technologies to children to produce predetermined outcomes' $(2007,7)$.

Additionally, there is a persistent evidence-based argument that, for young children, a prescribed, outcomes-driven curriculum, focused on formal skills in preparation for the next stage of education, is misinformed, developmentally inappropriate and potentially damaging (Moyles, Payler, and Georgeson 2014; Miller and Hevey 2012; Moyles 2012; MacNaughton and Hughes 2011; House 2011; Pound and Miller 2011; House and Loewenthal 2009; Gulberg 2009; Anning, Cullen, and Fleer 2004). In accordance with Moss $(2007,2013)$, Whitebread and Bingham $(2014,187)$ argue that 'if we wish to improve the quality of early education for all children, particularly those who are disadvantaged in some way we need to locate the problem, not in the children, but in inappropriate provision.' They argue that this schoolifying of the early childhood years flies in the face of research evidence. For example, Suggate (2009, 2011) found that there is no significant association between reading achievement and school entry. However, there was some evidence that children who start reading early developed less positive attitudes to reading (Suggate, Schaughency, and Reese 2013). They also cite longitudinal research evidence that points to the deleterious impact of early direct instruction on social and psychological frames of mind, and highlight the risks of skills-based performance on brain development (Blaustein 2005; Healy 2004). In addition, Whitebread and Bingham (2011) in their critical review of perspectives and evidence on school readiness are clear that, in contrast to an early focus on academic skills, there is copious research evidence relating to the positive impact of executive function (EF) skills (cognitive regulatory processes that underlie adaptive goal-directed responding to novel or challenging situations, [Bierman et al. 2008]) in supporting children's readiness for later academic learning. For example, Blair and Diamond (2008) found that school readiness is characterised by the development of cognition-emotion integration, and that self-regulation is significant in the coordination of systems relating to emotional arousal and cognitive control. Similarly, Bierman et al. (2008) concluded that EF skills appear widely related to later development in academic and social domains. They observe that much evidence underscores the importance of promoting self-regulation and self-competence as a means to foster the motivation, co-operation and focused persistence needed for learning. Whitebread and Bingham (2011) conclude that children's development, 
including EF skills, is fundamentally enhanced within particular contexts. This includes the need to experience emotional warmth and security, feelings of being in control of events and activities, and, experience of appropriate levels of cognitive challenge with opportunities to speak and reflect on their learning. In addition, they argue that playful contexts in which children are sensitively supported by adults are powerfully, perhaps uniquely, suited to providing these conditions in which young children thrive.

The Organisation for Economic Co-operation and Development (OECD) $(2006,59)$ observe this contrast in provision for young children in their exploration of the relationship between early years and compulsory school across Europe.

Broadly, one can distinguish two different approaches across countries. France and the English speaking countries see the question of partnership from the point of view of the (compulsory) school: early education should serve the objectives of public education and provide children with "readiness for school" skills. In contrast, countries inheriting a social pedagogical tradition (the Nordic countries and Central European countries) see kindergarten as a specific institution turned more to supporting families and the broad developmental needs of children.

There is, it seems, an observable schism between many in the community of early years research and practice and the current thrust of policy (Moss 2013; Moyles 2012; Miller and Hevey 2012; House 2011; Whitebread and Bingham 2011). So why this dichotomy? If there is a shared understanding of the importance of early years, and a commitment to children growing and learning during their early years, why are there deep and abiding differences in how this should be expressed in policy and enacted in practice?

Historically there has been a clear and accepted distinction between early years and school which, it will be argued, has resulted in very different pedagogic models. However, in England, the current political imperative to align early years with statutory schooling has challenged this distinction. 


\section{Discourses of children and childhood}

Understandings of 'childhood' and 'children,' whether explicit or implicit, shape dominant discourses about young children and inform policy and practice. These discourses create particular linked understandings and images of children in our society that emerge not from some grand design, but are constructed through a social process of assemblage across ways of thinking, talking and acting. Dahlberg, Moss, and Pence $(1999,62)$ recognise this process, commenting that, 'Institutions and pedagogical practices for children are constituted by dominant discourses in our society and embody thoughts, conceptions and ethics which prevail at a given moment in a given society.'

This assemblage has resulted in contemporary debates that vary in focus and emphasis and construct differing understandings of children and childhood (Moss and Petrie 2002) that have significant resonance with the educational provision made for our youngest children. Much analysis concludes that there is a strong, observable relationship between understandings of childhood and provision made for young children (Moss 2014; Whitebread and Bingham 2011; Moss 2007; Soler and Miller 2003; Moss and Petrie 2002; Prout 2000; Dahlberg, Moss, and Pence 1999; James and Prout 1997; Prout and James 1997; Edwards, Gardini, and Forman 1993). This analysis also concludes that the dominant discourse of childhood that is evident in current political rhetoric differs significantly from alternative discourses of children and childhood that 'foreground the culturally and socially constructed nature of learning' (Anning, Cullen, and Fleer 2004, 1).

\section{The dominant discourse, early years, policy and political rhetoric}

Moss (2014) argues that the dominant educational discourse in early years is embedded in the neo-liberal story of a global free market place. This, he argues, is a complex, contradictory place dominated by the ideas and language of competition, investment and return. Similarly, Ball (2007) observes that education is increasingly, perhaps almost exclusively, spoken of within policy documents in terms of its economic value and contribution to international market competitiveness.

However, as Moss (2014) notes, there are strong contradictions in the discourse as neoliberal calls for freedom and flexibility only extend, in education, to the means and not 
the ends. This is supported by Fendler (2001) who argues that flexibility in early years education pertains only to the course of action not to the outcome, as outcomes are intensely regulated and governed by the state. As Moss $(2014,69)$ observes,

this is no free market; it is intensely governed externally, by the state. There are national regulations covering standards, curriculum and learning, a national system of surveillance and inspection extending to every individual centre and childminder in the country; [and] a national system of assessment of young children's performance.

This discourse can be seen to have powerfully informed current early years policy and political rhetoric in the debate around school readiness. Elizabeth Truss MP, in the Department for Education's (DFE) report More Great Childcare (DFE 2013), sets out the government's vision for early education and childcare.

The evidence is clear that a good start in these early years can have a positive effect on children's development, preparing them for school and later life....It is also important for our wider society and economy. We are in a challenging global environment where we must make the best of everyone's talents. We need to support our children to be able to succeed in a world that is fast changing. And where the skills and knowledge of a nation's population are the best guarantee of their economic security and prosperity. (DFE 2013, 13)

Similarly, Wiltshire (Ofsted 2014a, 3) in his speech to launch Ofsted's first annual report on early years argues that 'too much [early years provision] is being delivered without a strong enough focus on the essential skills that a child needs to start school.'

The significance of Ofsted's assessment of school readiness cannot be underestimated. Its uniquely powerful position to influence policy, and enforce change through regimes of inspection, places them at the centre of the creation and maintenance of the dominant discourse. Wilshire (Ofsted 2014, 9) outlines what he considers constitutes school readiness, 'A child who is ready for school must have the physical, social and emotional tools to deal with the classroom, as well as the basic groundwork to begin to develop academically.' The thrust of the argument is towards supporting the poorest children, and the importance of this is expressed in social and economic terms,

Too many (of the poorest children) do badly by the end of primary and carry on doing badly at the end of secondary. Many of them, of course, end up not 
in education, employment or training (NEET) - unskilled and unemployable. If the gap isn't closed, the cost to our nation will run into billions. The Sutton Trust estimates that the UK's economy would see cumulative losses of up to $£ 1.3$ trillion in GDP over the next 40 years if the country fails to bring the educational outcomes of children from poorer homes up to the UK average. (OFSTED 2013, 3)

\section{An alternative discourse: children, childhood and early education}

An alternative discourse contests these notions of children and childhood and challenges current dominant policy-led understandings and provision for children. This discourse, articulated internationally within the Pedagogic Recontextualising Field (PRF) (Bernstein 2000, 33) ${ }^{1}$, stands in opposition to the instrumental view of early years as a place to ready children for schooling. In England its roots lie in the philosophy of Comenius (1592-1670) and Rousseau (1712-1778), the psychology of Piaget (1896-1980), Vygotsky (1896-1934) and Dewey (1859-1952), and the work of early years pioneers such as Pestalozzi (1746-1827), Froebel (1782-1852), Steiner (1861-1925), Montessori (1870-1952) and Isaacs (1885-1948) (Nutbrown and Clough 2013). Historically, this alternative discourse has shaped early years philosophy and practice, and, in England, it remains highly influential as the discourse that underpins philosophy and practice in the PRF (Whitebread and Bingham 2014; Bradbury 2012; Moyles 2012; House 2011; Soler and Miller 2003). This discourse finds strong resonance in the Reggio Emilia approach. Their approach articulates a way of seeing, understanding and providing for children that is regarded by many in the PRF as an affirmation (and aspiration) of an alternative discourse in practice; one that strongly accords with early years philosophy and practice articulated within the PRF in England (Atherton and Nutbrown 2016; Moyles, Payler, and Georgeson 2014; Moss 2014, 2013; House 2011; Abbot and Nutbrown 2001). This approach, outlined below from accounts of the founder Loris Malaguzzi, thus stands as a cohesive example of practice that embeds an alternative discourse of children, childhood and early education, (for critical discussion of the approach see Wood [2013] and Brembeck, Johansson, and Kampmann [2004]).

\footnotetext{
${ }^{1}$ Bernstein (2000) distinguishes between the Pedagogic Recontextualising Field (PRF): pedagogues in schools, colleges, departments of education, and specialised journals, and the Official Recontextualising Field (ORF): the state, agents and ministries.
} 
Deconstruction of dominant discourses of children and childhood has enabled staff in Reggio Emilia to construct a rich image of children and childhood, one that regards children as 'autonomously capable of making meaning from their daily lives and experiences through mental acts involving planning, coordination of ideas and abstraction' (Malaguzzi 1993a, 75). One of the most significant features of their provision is the emphasis on learning as a socially embedded process. Malaguzzi (1993a, 1993b) describes this as an education based on relationships. Learning is understood as being socially situated and socially constructed. The place of the child within learning is similarly carefully articulated. The rich child is expected to take an active role in the construction and acquisition of learning and understanding.

Malaguzzi (1993a, 4) specifically addresses the issue of time in early years provision, arguing that the measure of the clock is false for the subjective experience of childhood. Instead, he concludes that, 'One has to respect the time of maturation, of development, of the tools of doing and understanding, of the full, slow, extravagant, lucid and ever changing emergence of children's capabilities.'

The role of the teachers and pedagogista within the schools also recognises learning as a social process in which the child participates. The adult's role is,

to activate, especially indirectly, the meaning-making competencies of children as the basis of all learning. They must try to capture the right moments and then find the right approaches for bringing together, into a fruitful dialogue, their meanings and interpretations with those of the children. (Malaguzzi 1993a, 75)

Meanings are thus constructed alongside the child, with starting points and directions contingent on the child's interests and understanding. Children are understood as 'producers not consumers' (Malaguzzi 1993a, 66). As Malaguzzi observes, 'What children learn does not follow as an automatic result from what is taught. Rather it is in large part due to the children's own doing, as a consequence of their own activities and our resources' (59).

Observation and interpretation of learning processes are a critical aspect of the provision; what Malaguzzi refers to as reconnaissance. He notes that interpretation 
enables adults to find clues for supporting children's learning, for example how a child enters into an activity and develops strategies of thought and action or the ways in which objects involved are transformed. Adults therefore need to enter the time frame of the children.

Finally, an aspect of practice that characterises the approach in Reggio Emilia, and challenges dominant discourses, is the expectation of conflict and subversion. Malaguzzi (1993a) regards conflict as a necessary aspect of social exchange amongst children and adults, as, he notes, it unfolds problems in the cognitive, affective and expressive realms.

What is observable in this approach is an alignment of discourse and practice: the stated discourse of a child 'rich in potential, strong, powerful and competent' (Malaguizzi 1993, 10) informs, and is enacted in practice.

What is thus evident is that these two distinctly different discourses currently inform early years provision in England; the dominant discourse in the ORF, and an alternative discourse in the PRF, exemplified in the Reggio approach. Each sees the potential of young children and each recognises the importance of early education, but they differ profoundly in how this should be expressed in policy and enacted in practice. It can therefore be argued that one way of understanding the current troubled relationship between early years and early years policy on school readiness, is in the transformation of these discourses into practice.

Bernstein (2000) in his pedagogic device provides a theoretical framework for this transformation: the process whereby discourse becomes practice. He argues that this transformation starts with particular understandings, and results in particular pedagogical practices. Where discourse differs this transformation will almost inevitably result in different practices. Thus, one way of understanding the current situation in early years is that it is required to exist within the two distinctly different discourses outlined above, and these discourses, transformed into practice, demand very different approaches. An understanding of these process, using Bernstein's codes and modalities of practice, enables a theorised articulation of the troubled relationship 
between early years and early years policy exemplified in the current issue of school readiness.

\section{The transformation of discourse into practice}

Bernstein (2000) argues that the transformation of discourse into practice is the crucial step in the pedagogisation of knowledge, and can be understood as a series of transformations starting at an abstract level and moving in steps towards practice. His account of the transformation of discourse into practice identifies two contrasting pedagogic models that flow from the different conceptualisations at each stage of the transformation: a Competence model and a Performance model.

Bernstein identifies three levels of transformation in the pedagogic device [Fig. 1]. At the most abstract level, he argues, pedagogic discourse specialises meanings to time and space thus bringing together time, text and space in a specific relationship. At the next level these abstract formulations are transformed to a 'more obvious real level' (Bernstein 2000, 35); time becomes age, text becomes content, and space becomes context. Finally, age, content and context are transformed 'to the level of the social relations of pedagogic practice and the crucial features of communication' (36) namely, acquisition, evaluation and transmission.

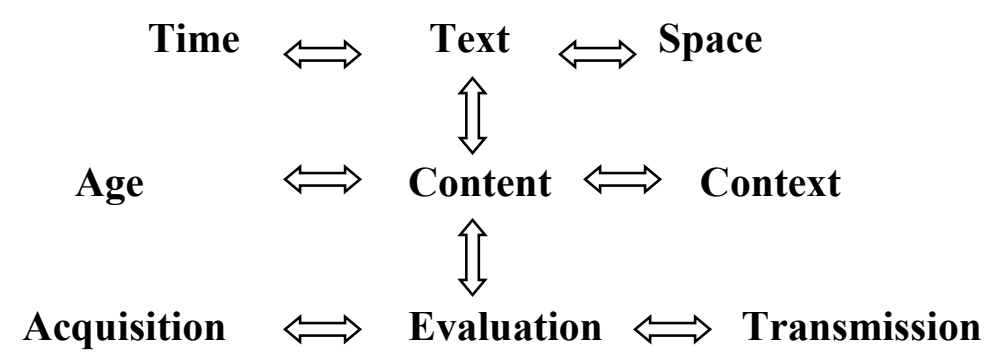

Figure 1: The Pedagogic Device. (Bernstein, 2000:36)

It therefore follows that where discourse differs in conceptualisations of time, text and space, these, transformed through the levels of the pedagogical device, will result in differing pedagogical models. This, it can be argued, is the current position in early 
years with regard to the issue of school readiness: the debate is informed by two distinctly different discourses, which, transformed into practice, require very different pedagogical models. Bernstein (2000) terms these pedagogical models Competence and Performance [Table 1].

Conflicting pedagogies: the troubled relationship between early years and early years policy

\section{Competence and Performance pedagogies}

A Competence model flows from a concept of competence evident in competence theories. Recontextualised, this notion of competence constructed a specific pedagogic practice: a Competence model. This pedagogic model is characterised by an emphasis on the realisation of competencies. It has a learner-centred orientation to the context and content of learning and an expectation of multiple texts as representations of learning. The model necessitates personalised criteria for evaluation as the emphasis is on what is present in a child's learning. In this model professional autonomy is high, and professionalism inheres in 'reading the text' that the child produces. In contrast, Bernstein $(2000,44)$ identifies a Performance model as placing emphasis upon, 'a specific output of the acquirer, upon a particular text the acquirer is expected to construct, and upon the specialised skills necessary to the production of this specific output, text or product.'

\begin{tabular}{|l|l|}
\hline Competence & Performance \\
\hline $\begin{array}{l}\text { Emphasis is on a range of experiences } \\
\text { over which the child has considerable } \\
\text { control over selection, sequence and } \\
\text { pace. Emphasis is on the realisation of } \\
\text { competencies }\end{array}$ & $\begin{array}{l}\text { Emphasis is on the acquisition of skills } \\
\text { and procedures which are clearly } \\
\text { identifiable thus children have less } \\
\text { pace of learning as texts are explicit }\end{array}$ \\
$\begin{array}{l}\text { Few defined pedagogical spaces. Space is } \\
\text { used fluidly and children have } \\
\text { considerable control over the } \\
\text { construction of the space. }\end{array}$ & Space is clearly defined and access and \\
movement explicitly regulated
\end{tabular}




\begin{tabular}{|l|l|}
\hline $\begin{array}{l}\text { The text is an indicator of competency } \\
\text { and the teacher operates by 'reading } \\
\text { through' the text offered. } \\
\text { Professionalism inheres in the reading of } \\
\text { texts. }\end{array}$ & $\begin{array}{l}\text { the } \\
\text { performance criteria. Professionalism } \\
\text { inheres in the application of specific } \\
\text { pedagogical practices and grading } \\
\text { procedures }\end{array}$ \\
\hline $\begin{array}{l}\text { Evaluation emphasises what is present in } \\
\text { the children's learning. It asks what can } \\
\text { the child do? Criteria for evaluation are } \\
\text { therefore personalised and diffuse }\end{array}$ & $\begin{array}{l}\text { Emphasis is on what is missing in the } \\
\text { child's learning. Criteria for evaluation } \\
\text { are therefore explicit and specific and the } \\
\text { child will be made aware of how to } \\
\text { produce the expected text }\end{array}$ \\
\hline $\begin{array}{l}\text { Requires a high level of autonomy for } \\
\text { teachers to construct and develop their } \\
\text { professional practice }\end{array}$ & $\begin{array}{l}\text { Autonomy within professional practice is } \\
\text { subordinate to external curricula and } \\
\text { regulation of selection, sequence, pace } \\
\text { and criteria for teaching and learning. }\end{array}$ \\
\hline
\end{tabular}

Table 1: Competence and Performance pedagogies. Based on Bernstein (2000)

\section{A theoretical framework}

These differing pedagogical practices can be aligned with the outlined discourses: the dominant discourse and an alternative discourse.

A Performance model is closely aligned with the dominant discourse. It is evident in current political rhetoric and policy, across all phases of schooling, in the emphasis on the acquisition of pre-determined knowledge and skills that are closely managed and assessed against explicit criteria. Pedagogically this manifests in strong control over who does what, when and how. In contrast, a Competence model aligns with an alternative discourse. The emphasis is on a fluid response to children as individuals, starting from what they currently know and can do, and is focused on learning as a shared, socially constructed endeavour. Pedagogically therefore, there is more diffuse control over who does what, when and how. 
The current issue of school readiness sits at an intersection of these two distinctly different discourses, and the resulting pedagogical expectations at the level of practice are difficult to reconcile (Basford and Bath 2014; Moss 2014; Soler and Miller 2003).

School readiness within the dominant discourse results in a Performance pedagogical model. It is focused on the future in that early years is regarded as a preparation for school, and is therefore defined by the next stage of education. Knowledge and skills are thus acquired in preparation for what comes next. This requires pre-determined outcomes to ensure that children acquire appropriate skills and knowledge by a predetermined point in time. To manage and monitor readiness for school, these outcomes then become the basis of assessment in which pre-defined skills and knowledge are mapped to age-related norms, and assessed against explicit criteria. This is evident in the aspiration for a nationally comparable, standardised baseline assessment (DFE 2014). Pedagogically therefore, significant control over the selection, sequence, timing and pace of learning is required to ensure that both the early years sector and children's learning are aligned with later schooling. This control extends to professional practice, as facilitation of a Performance pedagogical model requires that autonomy becomes subordinate to external curricula, and regulation of the selection, sequence, pace and criteria for teaching and learning.

In contrast, being ready for school framed within an alternative discourse results in a Competence pedagogical model. A Competence pedagogical model is predicated on a child as an individual, a child whose learning is understood to take place within a specific context and specific relationships. There is therefore an expectation that learning may take different pathways and occur within different time frames. Agerelated or pre-defined criteria can therefore only act as a framework for reference. This model anticipates the future in recognising that early years is an intense period of growth, development and learning, but the focus is on the present. Pedagogically this requires fluidity and responsiveness to the selection, sequence, timing and pace of each individual child's learning. It also requires a significant level of professional autonomy for practitioners to construct and develop their professional practice. 
Thus, the early years sector finds itself working in a place of tension and contradiction: at the intersection of two discourses which, transformed into practice, require different pedagogical approaches. This has significant consequences for early years as policies framed within the dominant discourse, and fuelled by powerful political rhetoric, are applied to the sector. The underpinning tenets of early years practice in the PRF are therefore placed in conflict with policy imperatives on school readiness (Moss 2013, 2007; House 2011; Whitebread and Bingham 2011).

In addition, what can be observed is significant potential for the dominant discourse to prevail. The effect of this instrumental view of early years education is magnified by stated learning outcomes and regimes of inspection that result in a rapid impact of policy and rhetoric on practice. Policy acts swiftly on practice through statutory requirements. These are framed within the dominant discourse of time, text and space, which are transformed into age defined notions of context and content and, in turn, define transmission, acquisition and evaluation at the level of practice (Bernstein 2000). This then becomes cyclical, as the demands of evaluation begin to inform understandings of time text and space. In this way the politically driven changes in discourse result in enforced pedagogical change in the early years.

\section{Discussion}

The policy focus on school readiness in England is informed by ongoing concern about the achievement gap between the poorest and those from more advantaged backgrounds. Its stated aims are three fold: to help improve outcomes; to enable identification and early intervention for potential problems (Ofsted 2014b); and to counter the effects of socio-economic disadvantage (Ofsted 2014c). Logic therefore dictates that a change in pedagogical model should have a high chance of facilitating the stated aims. Thus, the question arises; is a shift from a Competence to a Performance pedagogical model likely to achieve these aims? Significantly, Moss $(2010,555)$ argues that, for Bernstein, neither pedagogy is an absolute good: neither is capable of being judged by its instrumental efficacy alone but there are 'social costs and social investments of running with one rather than the other.' So a more precise question is whether this pedagogical shift from Competence to Performance is appropriate to improve outcomes for socio-economically disadvantaged young children in the context of becoming ready for school? The evidence is not reassuring. 
Bernstein argues that different pedagogical models require individuals to orientate themselves to what is expected, and to enact it in a particular way. The ability to orientate themselves to these rules of recognition and realisation determine the extent to which children are able to 'read' the demands of a particular context and put meanings together to create, and make public, the required (legitimate) text. 'Text' for Bernstein $(2000,18)$ is 'anything that attracts evaluation.' In a Competence model, these rules of recognition and realisation are more fluid, child-focused and diffuse than in a Performance model, in which the rules are prescribed, outcome-focused and visible. Bernstein argues that certain distributions of power give rise to different social distributions of recognition and realisation rules and that without these the production of contextually legitimate texts and communicative practices are not possible. He identifies children from the 'marginal classes' (17) as children who are likely to be disadvantaged by a more limited ability to recognise and/or realise visible schoolbased discourses. Moss (2000) concludes similarly; her study of informal literacies and pedagogical discourse showed that school knowledge was visible and inclusive to middle-class children, whilst working-class children did not represent school knowledge structures in the same way. She concludes that her work offers a bleak view of working-class children's schooling. Bradbury's study also supports Bernstein's assertion. Bradbury argues that the transition of children in early years into recognisable student-subjects is dependent upon the adoption of a series of values and behaviours. She concludes that the current 'restrictive notion of what a 'good learner' looks like can work to systematically exclude some children from positions of success' (Bradbury 2012, 1), and observes that it is middle-class children, whose parents have invested in a range of activities and experiences for their children, who benefit most from a restrictive pedagogical approach.

It can therefore be argued, that instead of supporting school readiness in line with stated policy aims the shift to a Performance pedagogical model in early years may disadvantage the children who are its main focus. There is evidence to suggest that the emphasis on pre-determined outcomes, pre-determined timeframes, assessment against explicit criteria, and the necessary control over the selection, sequence, timing and pace of learning may not meet the needs of children whose experiences beyond school limit their ability to recognise and/or realise school-based discourses. 


\section{Conclusion}

The debate around school readiness exemplifies the ongoing troubled relationship between early years and early years policy and political rhetoric. It is a debate in which all sides recognise the importance of a child's earliest years of education, but differ profoundly in their understanding of how this should be manifest in policy and enacted in practice. The issue of school readiness in England thus exists in a place of tension, with a politically driven change in early years discourse resulting in enforced pedagogical changes. This, it has been argued, has limited potential for achieving stated policy aims. Thus, it seems that if the stated aims (Ofsted 2014b, 2014c) are to be met there needs to be a policy level reconceptualisation of school readiness that takes account of the evidence about what actually enables children to be ready for school (Whitebread and Bingham 2011; Bierman et al. 2008). Additionally, the corollary of the limitations of a Performance pedagogical model in enabling children to be ready for school is not that a Competence pedagogical model will necessarily achieve this. Therefore, it is important that the early years community of research and practice continue to question embedded practices within the Competence model, so that we don't create new doxa: unstated taken-for-granted assumptions (Kalliala 2013). Challenges to existing pedagogy is evident in the work of Wood (2013), Kalliala (2013) and Brembeck, Johansson, and Kampmann (2004) who, within a commitment to a Competence model, raise important questions about who is advantaged and who disadvantaged by early years pedagogical practice articulated within the PRF.

Sir Michael Wilshaw (2014a, 2) makes the obvious point that 'No one questions the importance of investing early in a child's education.' However, as Camus (Tan 2005) cautions, 'Good intentions may do as much harm as malevolence if they lack understanding.' 


\section{References}

Abbot, L., and C. Nutbrown. 2001. Experiencing Reggio Emilia. Buckingham: Open University Press.

Alexander, R. 2009. Children, Their World, Their Education: Final Report and Recommendations of the Cambridge Primary Review. London: Routledge.

Anning, A., J. Cullen, and M. Fleer. 2004. Early Childhood Education. Society and Culture. London: Sage.

Atherton, F., and C. Nutbrown. 2016. "Schematic Pedagogy: Supporting One Child's Learning at Home and in a Group." International Journal of Early Years Education 24 (1): 63-79. DOI: 10.1080/09669760.2015.1119671.

Ball, S. 2007. Education PLC: Understanding Private Sector Participation in Public Sector Education. London: Routledge.

Basford, J., and C. Bath. 2014. "Playing the Assessment Game: an English Early Childhood Perspective." Early Years 34 (2): 119-132.

DOI:10.1080/09575146.2014.903386

Bernstein, B. 2000. Pedagogy, Symbolic Control and Identity. Theory, Research, Critique. London: Rowman and Littlefield.

Bierman, K., R. Nix, M. Greenberg, C. Blair, and C. Domitrovich. 2008. "Executive Functions and School Readiness Intervention." Development and Psychopathology 20(3): 821-843. DOI: 10.1017/S0954579408000394

Blair, C., and A. Diamond. 2008. "Biological Processes in Prevention and Intervention: The Promotion of Self-Regulation as a Means of Preventing School Failure." Development and Psychopathology 20(3): 899-911.

Blaustein, M. 2005. "See! Hear! Touch! The Basics of Learning Readiness." Journal of the National Association for the Education of Young Children 41 (1): 45-7.

Bradbury, A. 2012. "Education Policy and the Ideal Learner." British Journal of Sociology of Education 34(1): 1-19. DOI: 10.1080/01425692.2012.692049

Brembeck, H., B. Johansson, and J. Kampmann. 2004. Beyond the Competent Child. Roskilde: Roskilde University Press.

Burger, K. 2010. "How Does Early Childhood Care and Education Affect Cognitive Development? An International Review of the Effects of Early Interventions for Children from Different Social Backgrounds." Early Education Research Quarterly 25(2): 140-165.

Dahlberg, G. 2013. "A Dialogue with the Co-author of The Vision of a Meeting Place." In Early Childhood and Compulsory Education: Reconceptualising the Relationship, edited by Peter Moss, 72-90. London: Routledge. 
Dahlberg, G. 2000. "Everything Is Beginning and Everything Is Dangerous." In Early Childhood Services. Theory, Policy and Practice, edited by Helen Penn, 175-184. Buckingham: Open University Press.

Dahlberg, G., P. Moss, and A. Pence. 1999. Beyond Quality in Early Childhood Education and Care: Postmodern Perspectives. London: FalmerBooks.

DFE (Department for Education). 2014. "Reforming Assessment and Accountability for Primary Schools."

https://www.gov.uk/government/uploads/system/uploads/attachment_data/file/297595 /Primary_Accountability_and_Assessment_Consultation_Response.pdf

DFE/IOE (Department for Education/Institute of Education). 2014. "Students'

Educational and Developmental Outcomes at Age 16. Effective Pre-school, Primary and Secondary Education (EPPSE 3-16) Project."

http://www.ioe.ac.uk/images/Research_Briefings_231x211/RB354 -

_Students_educational_and_developmental_outcomes_at_age_16_Brief.pdf

DFE (Department of Education). 2013. "More Great Childcare. Raising Quality and Giving Parents More Choice."

https://www.gov.uk/government/uploads/system/uploads/attachment_data/file/219660 /More_20Great_20Childcare_20v2.pdf

Dockett, S., and B. Perry. 2013. "Trends and Tensions: Australian and International Research About Starting School.” International Journal of Early Years Education 21 (2-3): 163-177. DOI:10.1080/09669760.2013.832943

Edwards, C., L. Gardini, and G. Forman. 1993. Hundred Languages of Children. The Reggio Emilia Approach to Early Childhood Education. New Jersey: Ablex Publishing.

Fendler, L. 2001. Educating Flexible Souls: The Construction of Subjectivity Through Developmentality and Interaction.

https://www.academia.edu/10638358/Fendler L. 2001 . Educating flexible souls The construction of subjectivity through developmentality and interaction. In K. Hultqvist and G. Dahlberg Eds. Governing the child in the new millennium $p$ p. 119-142. New York RoutledgeFalmer

Georgeson, J., and J. Payler. 2013. International Perspectives on Early Childhood. Berkshire: Open University Press.

Gulberg, H. 2009. Reclaiming Childhood: Freedom and Play in an Age of Fear. Abingdon: Routledge.

Haug, P. 2013. "From Indifference to Invasion: The Relationship from a Norwegian Perspective." In Early Childhood and Compulsory Education: Reconceptualising the Relationship, edited by Peter Moss, 114-129. London: Routledge.

Healy, J. M. 2004. Your Child's Growing Mind. $3^{\text {rd }}$ ed. New York: Broadway Books. 
House, R. 2011. Too Much Too Soon. Early Learning and the Erosion of Childhood. Stroud: Hawthorne Press.

House, R., and D. Loewenthal. 2009. Childhood, Well-Being and a Therapeutic Ethos. London: Karnac.

James, A., and A. Prout. 1997. "Re-Presenting Childhood: Time and Transition in the Study of Childhood." In Constructing and Reconstructing Childhood, edited by Allison James and Alan Prout, 227-247. London: RoutledgeFalmer.

Kalliala, M. 2013. "Toddlers as More and Less Competent Social Actors in Finnish Day Care Centres." Early Years: An International Research Journal 34 (1): 4-17. DOI:10.1080/09575146.2013.854320

Malaguzzi, L. 1993b. "For an Education Based on Relationships." Young Children 49 (1): 9-12.

Malaguzzi, L. 1993a. "History, Ideas and Basic Philosophy." In The Hundred Languages of Children, edited by Carolyn Edwards, Lella Gandidi, George Forman, 41-91. New Jersey: Ablex Publishing.

McNaughton, G., and P. Hughes. 2011. Parents and Professionals in Early Childhood Settings. Berkshire: Open University Press.

Miller, L., and D. Hevey. 2012. Policy Issues in the Early Years. London: Sage.

Moss, G. 2010. "Literacy and Pedagogy in Flux." British Journal of Sociology of Education 23 (4): 549-558. DOI 10.1080/0142569022000038404

Moss, G. 2000. "Informal Literacies and Pedagogic Discourse." Linguistics and Education 11 (1): 47-64. DOI: 10.1016/S0898-5898(99)00017-0

Moss, P. 2014. Transformative Change and Real Utopias in Early Childhood Education. London: Routledge.

Moss, P. 2013. "The Relationship between Early Childhood and Compulsory Education. A Properly Political Question." In Early Childhood and Compulsory Education: Reconceptualising the Relationship, edited by Peter Moss, 2-49. London: Routledge.

Moss, P. 2007. "Bringing Politics into the Nursery: Early Childhood Education as a Democratic Practice." European Early Childhood Education Research Journal 15 (1): 5-20.

Moss, P., and P. Petrie. 2002. From Children's Services to Children's Spaces. London: RoutledgeFalmer.

Moyles, J. 2012. Unhurried Pathways. Early Childhood Action. http://www.earlychildhoodaction.com/docs/ECA\%20EYF\%20Unhurried\%20Pathway s.pdf 
Moyles, J., J. Payler and J. Georgeson. 2014. Early Years Foundations: Critical Issues. 2nd ed. Berkshire: Open University Press.

Nutbrown, C., and P. Clough. 2013. Early Childhood Education. History, Philosophy and Experience. London: Sage.

Ofsted (Office for Standards in Education). 2014c. "Are You Ready? Good Practice in School Readiness."

http://www.ofsted.gov.uk/resources/are-you-ready-good-practice-school-readiness

Ofsted (Office for Standards in Education). 2014b. "The Report of Her Majesty's Chief Inspector of Education, Children's Services and Skills. Early Years.”

http://www.ofsted.gov.uk/earlyyearsannualreport1213

Ofsted (Office for Standards in Education). 2014a. "Unsure Start."

http://webarchive.nationalarchives.gov.uk/20141124154759/http://www.ofsted.gov.u $\mathrm{k} /$ sites/default/files/documents/about-

ofsted/speeches/Early\%20Years\%20Annual\%20Report\%201213\%20-

$\% 20$ Unsure\%20start\%20-\%20HMCI\%20speech.pdf

Ofsted (Office for Standards in Education). 2013. "Unseen Children: Access and Achievement 20 Years On.”

http://www.ofsted.gov.uk/resources/unseen-children-access-and-achievement-20years

Organisation for Economic Co-operation and Development (OECD). 2006. "Starting Strong II Early Childhood Education and Care."

http://www.oecd.org/newsroom/37425999.pdf

Pound, L., and L. Miller. 2011. "Critical Issues.” In Theories and Approaches to Learning in the Early Years, edited by Linda Miller and Linda Pound, 163 - 172. London: Sage.

Prout, A. 2000. "Children's Participation: Control and Self-Realisation in British Late Modernity." Children and Society 14: 304-315.

Prout, A., and A. James. 1997. "A New Paradigm for the Sociology of Childhood?" In Constructing and Reconstructing Childhood, edited by Allison James and Alan Prout, 7-33. London: RoutledgeFalmer.

Schweinhart, L., J. Montie, Z. Xiang, S. Barnett, C. Belfield, and M. Nores. 2005. "Lifetime Effects: The HighScope Perry Preschool Study Through Age 40." http://www.highscope.org/file/Research/PerryProject/specialsummary rev2011_02_2. $\underline{\mathrm{pdf}}$

Soler, J., and L. Miller. 2003. "The Struggle for Early Childhood Curricula. A Comparison of the English Foundation Stage Curriculum, Te Whariki and Reggio Emilia." International Journal of Early Years Education 11 (1): 57-68. 
Stagg, L. 2012. "The Rhetoric and Reality of a National Strategy for Early Education and Assessment." In Policy Issues in the Early Years, edited by Linda Miller and Denise Hevey, 139-153. London: Sage.

Standards and Testing Agency. 2016. Reception Baseline Comparability Study. https://www.gov.uk/government/publications/reception-baseline-comparability-study

Suggate S. 2011. "Viewing the Long Term Effects of Early Reading with an Open Eye." In Too Much Too Soon. Early Learning and the Erosion of Childhood, edited by Richard House, 236-247. Stroud: Hawthorne Press.

Suggate, S. 2009. "School Entry Age and Reading Achievement in the 2006 Programme for International Student Assessment (PISA)." International Journal of Educational Research 48: 151-61.

Suggate, S., E.A. Schaughency, and E. Reese. 2013. "Children Learning to Read Later Catch up to Children Reading Earlier." Early Childhood Research Quarterly 28 (1): 33-48.

Tan, A. 2005. Saving Fish from Drowning. London: Fourth Estate.

Vandenbroeke, M., N. De Stercke, and H. Gobeyn. 2013. "What If the Rich Child Has Poor Parents?" In Early Childhood and Compulsory Education:

Reconceptualising the Relationship, edited by Peter Moss, 174-191. London:

Routledge.

Whitebread D., and S. Bingham. 2014. "School Readiness: Starting Age, Cohorts and Transitions in the Early Years." In Early Years Foundations: Critical Issues. 2nd ed, edited by Janet Moyles, Jan Georgeson, and Jane Payler, 179-191. Berkshire: Open University Press.

Whitebread, D., and S. Bingham. 2011. "The Readiness Literature Review." TACTYC http://tactyc.org.uk/occasional-papers/

Wood, E. 2013. "Free Choice and Free Play in Early Education: Troubling the Discourse." International Journal of Early Years Education 22: (1) 4-18.

DOI: 10.1080/09669760.2013.830562 